\title{
A ESPECIALIZAÇÃO DOS PROCEDIMENTOS LITIGIOSOS DE FAMÍLIA NO CÓDIGO DE PROCESSO CIVIL DE 2015 COMO GARANTIA DO DIREITO AO PROCEDIMENTO ADEQUADO
}

\author{
Edenilza Gobbo* \\ Mônica Locatelli**
}

Resumo: O Código Processual Civil de 2015 trouxe inúmeras inovações, dentre elas, a previsão de um procedimento especializado às ações litigiosas de família. Porém, será que tal especialização garante um procedimento adequado que efetive o acesso à justiça? Buscando respostas, esse artigo traz uma análise do procedimento concebido pelo Código aos litígios de família, bem como a melhor maneira em alcançar-se um procedimento adequado e garantidor da efetiva justiça. Conclui-se que a intenção do legislador em ofertar procedimentos que tenham maior afinidade com o direito material em litígio pode facilitar o acesso à justiça além de atingir a esperada tutela estatal.

Palavras-chave: Processo civil. Acesso à justiça. Direito ao procedimento adequado. Procedimentos especiais. Ações de família.

\section{THE SPECIALIZATION OF FAMILY LITIGATION PROCEDURES IN THE 2015 CIVIL PROCEDURE CODE AS A GUARANTEE OF THE RIGHT TO APPROPRIATE PROCEDURE}

\begin{abstract}
The 2015 Civil Procedure Code has brought innumerable innovations, among them, the prediction of a specialized procedure for family actions. But has the specialization been able to successfully guarantee an appropriate procedure that ensures the access to justice? Seeking answers, this article shows a analysis of the new procedure designed by the Code, as well as the best strategy to achieve an adequate procedure that guarantees the effective justice. It is concluded that the intention of the legislator to offer procedures that have a greater affinity with substantial law in litigation can facilitate the access to the justice.
\end{abstract}

Keywords: Civil procedure. Access to justice. Right to appropriate procedure. Special procedures. Family actions.

\section{INTRODUÇÃO}

\footnotetext{
* Mestre em direito pela Universidade Federal de Santa Catarina; professora titular do curso de Direito da Universidade do Oeste de Santa Catarina além de atuar em curso de Pós-Graduação e advogada Especialista em Direito Civil. Sua pesquisa concentra-se nas áreas de Direito de Família e Direito da Criança e do adolescente. Atua na área do Direito das Famílias, Sucessões, Processo Civil, Criança e Adolescente e o Estatuto da Pessoa com Deficiência. Endereço postal: Rua Oiapoc, 1864, no Centro de São Miguel do Oeste - SC, CEP 89900-000. E-mail: edenilza.gobbo@unoesc.edu.br.

** Especialista em processo civil pela Universidade do Oeste de Santa Catarina. Advogada atuante na área civil. Graduada em Direito pela Universidade do Oeste de Santa Catarina (2016). Endereço postal: Rua Duque de Caxias, 1188, sala 05 - Ed. Aquarius, no Centro de São Miguel do Oeste - SC. CEP 89900-000. E-mail: monilocatelli@hotmail.com.
} 
$\mathrm{O}$ prestigiado direito de acesso à justiça, com assento no art. $5^{\circ}, \mathrm{XXXV}$ da Carta Magna, ganhou maior evidência ao passo que o homem, reconhecendo e positivando uma série de direitos inerentes ao convívio em coletividade, observou a necessidade de que, mais que criar tais direitos, seria primordial garantir-lhes efetividade por intermédio da tutela jurisdicional. Entretanto, como efetivar o acesso à justiça?

A ideia de que um procedimento uniforme pudesse ser condizente a todas as demandas que batem às portas do Poder Judiciário vem perdendo força na proporção em que se vislumbra que técnicas processuais individualizadas e especializadas ao direito material em discussão proporcionam um processo mais célere, adequado e econômico, enfim, um acesso à justiça mais eficiente.

Pensando nisso, o Conselho Nacional de Justiça publicou, ainda no ano de 2010, sua Resolução de $n^{\circ} 125$ que promoveu novas formas de resolução de conflitos, em especial mecanismos consensuais de solução de contendas, além de buscar estimular, apoiar e difundir práticas amigáveis já adotadas pelos Tribunais.

Ao encontro desses novos rumos vislumbrados ao processo civil, e sabendo-se que o direito de família é complexo em sua natureza por não tratar somente de bens materiais, mas de relações interpessoais e toda a sua afetividade e fragilidade decorrentes, foi que o legislador previu um procedimento específico às demandas contenciosas de família no recente e vigente Código de Processo Civil.

Se o Código Processual Civil de 2015 como um todo já demonstrou forte preocupação em fomentar meios consensuais de resolução de conflitos, a atenção é redobrada no que tange as demandas que envolvam direitos de família. Já em seu art. $3^{\circ}$, o diploma legal reproduz a garantia constitucional do direito ao acesso à justiça, reconhece e autoriza o uso da arbitragem, bem como clama para que os operadores do direito estimulem o uso da conciliação e da mediação a qualquer tempo no curso do processo.

Tendo por base o enredo supra, o presente artigo busca verificar se a especialização dos procedimentos litigiosos de família, em especial a partir das novas diretrizes estabelecidas pelo Código de Processo Civil de 2015, pode servir como garantia de efetividade do direito ao procedimento adequado.

Para facilitar a compreensão acerca do tema, o presente artigo se apresentará em três seções, sendo que a primeira abordará o conceito de acesso à justiça, as barreiras que obstaculizam sua realização e sua relação com o direito ao procedimento adequado. Num 
segundo momento, tratar-se-á dos procedimentos especiais ofertados pelo Código Processual de 2015 à família. Por fim, procurar-se-á responder se o legislador obteve êxito quanto à efetividade do direito ao procedimento adequado, ao ofertar procedimentos especiais aos litígios de família no Código de Processo Civil de 2015.

\section{O DIREITO AO PROCEDIMENTO ADEQUADO COMO COROLÁRIO DO DIREITO FUNDAMENTAL DE ACESSO À JUSTIÇA}

Dentre todos os valores, o mais amplo, completo e aspirado pelo homem é a justiça. Esta, por sua vez, já foi conceituada por uma série de autores, sendo semelhante dentre eles, a noção de que a justiça esteja sempre atrelada à de igualdade (BEZERRA, 2001).

Para além do conceito de justiça, é grande a preocupação do homem em garantir meios e métodos capazes de efetivar o acesso a esta conceituada justiça. Nesse norte, se o termo justiça é diferente de acesso à justiça, como então definir esse direito?

Também denominado de "acesso à ordem jurídica justa", "inafastabilidade da jurisdição" ou "inafastabilidade do controle jurisdicional", o direito constitucional de acesso à justiça, atualmente, encontra abrigo legal no art. $5^{\circ}, \mathrm{XXXV}$ da Constituição Federal, quando determina que "a lei não excluirá da apreciação do Poder Judiciário lesão ou ameaça a direito" (BUENO, 2017).

Cappelletti e Garth (1988) ressaltam que o direito de acesso à justiça tem sofrido importantes transformações, estas correspondentes às mudanças vislumbradas no estudo do processo civil. Entendia-se inicialmente que por ser o acesso à justiça um direito natural e, sendo tais direitos anteriores ao Estado, os mesmos não estariam sujeitos a uma proteção jurisdicional. Nesse norte, o Estado permanecia inerte quanto à capacidade dos indivíduos de reconhecerem e defenderem seus próprios direitos na prática.

O crescimento das sociedades deu margem a uma nova visão acerca de direitos humanos, dessa vez mais coletiva que individual. Com as Declarações de Direitos dos séculos XVIII e XIX, e as novas Constituições que buscaram outorgar direitos sociais como à saúde, à educação, ao trabalho e à segurança, passou a ser cada vez mais comum a atuação positiva e necessária do Estado para confirmar o acesso a esses direitos sociais básicos. Nesse contexto, Cappelletti e Garth (1988, p. 12) acreditam que “o acesso à justiça pode, portanto, ser encarado como o requisito fundamental - o mais básico dos direitos humanos - de um sistema

Rev. de Processo, Jurisdição e Efetividade da Justiça | e-ISSN: 2525-9814 | Porto Alegre | v. 4 | n. 2 | p. $43-65$ | Jul/Dez. 2018 
jurídico moderno e igualitário que pretenda garantir, e não apenas proclamar os direitos de todos."

Para Câmara (2004) o direito de acesso à justiça não deve ser entendido tão somente como a possibilidade formal de mover-se o Judiciário, propondo ação ou dela defendendo-se, eis que seria uma garantia ineficaz, inútil, uma falsa garantia. Para além, acredita que o direito em questão deva ser encarado como uma garantia de acesso à ordem jurídica justa, ou seja, uma garantia substancial, onde titulares de direito possam alcançar uma efetiva e verdadeira tutela Estatal.

A importância do direito em estudo é tamanha, que o mesmo fora praticamente transcrito no art. $3^{\circ}$ do jovem Código de Processo Civil: "Não se excluirá da apreciação jurisdicional ameaça ou lesão a direito."

É importante tornar claro que, ao declarar expressamente que o Poder Judiciário tem o dever de não somente reparar lesões suportadas num tempo passado, mas também buscar evitar a consumação de danos que possam vir a ser suportados em um dado momento futuro, o dispositivo em apreço, nem de longe, visou afastar, impedir ou obstaculizar a solução de litígios por intermédio de meios consensuais, como se o Judiciário fosse a única opção viável (BUENO, 2015).

Pelo contrário, consoante elucida Bezerra (2001), o direito fundamental de acesso à justiça não se exaure com a possibilidade de litigar em juízo e usufruir dos meios processuais ofertados pelo Estado. É necessário que se tenha uma visão mais ampla desse direito, entendo-o como um direito de viabilizar o acesso a uma ordem jurídica justa, seja judicial ou extrajudicialmente.

Além disso, o acesso à justiça depende da observância de outras garantias por parte do Judiciário e seus órgãos; tais como a impessoalidade da jurisdição, a motivação das decisões, o contraditório, o devido processo legal, a publicidade, a duração razoável do processo, o duplo grau de jurisdição e, até mesmo, o respeito à dignidade humana (THEODORO JÚNIOR, 2017).

Assim, buscando identificar e suprimir possíveis barreiras de acesso à justiça, Cappelletti e Garth (1988) definem as custas judiciais e os honorários advocatícios como um dos maiores empecilhos àqueles que pretendem buscar soluções nos Tribunais.

Não disforme, Bezerra (2001) acredita que o uso quase que exclusivo do judiciário para a resolução de conflitos, bem como as despesas inerentes a esse sistema, seja com 
advogado, honorários sucumbenciais, ou inclusive com as custas do próprio Judiciário, desestimulam os menos favorecidos a buscarem o que lhes é de direito, levando o cidadão a desiludir-se perante o que chama de "justiça".

O efetivo acesso à justiça fica mais inatingível quando se fala da morosidade que atualmente acompanha as demandas processuais. Além de aumentar as despesas processuais, a morosidade processual nada mais é que o próprio descumprimento da função do Poder Judiciário, eis que a inexistência de decisão em momento adequado, ou o seu proferimento tardio, também constitui um acesso à justiça deficiente e injusto (RODRIGUES, LAMY, 2016).

Por seu turno, as condições pessoais dos litigantes também se tornam obstáculos de acesso à justiça quando cidadãos carentes, de baixa renda e parca escolaridade, são submetidos a formalidades e solenidades com as quais não detém nenhuma afinidade. "As palavras difíceis, a forma aperfeiçoada, a elegância na maneira de se pronunciar e vestir são fatores que inibem a própria desenvoltura do chamado cidadão de direito" (CAOVILLA, 2006, p. 50).

Pensando nos empecilhos supramencionados, Cappelletti e Garth (1988) observaram movimentos de aprimoramento de acesso à justiça, aos quais denominaram de ondas renovatórias. A primeira onda trata da assistência judiciária aos pobres e se relaciona com obstáculos de cunho econômico de acesso à justiça. Por sua vez, a segunda onda refere-se a representação dos interesses difusos em juízo, buscando contornar o obstáculo organizacional de acesso à justiça. Por fim, a terceira onda, intitulada de "um novo enfoque de acesso à justiça" abriga a concepção mais ampla de acesso à justiça e prioriza uma reforma procedimental, bem como o maior e melhor preparo do aplicador do direito (CAPPELLETTI; GARTH, 1988).

Nesse norte, a interpretação do princípio do acesso à justiça não pode se limitar ao mero ingresso em juízo, pelo contrário deve compreender uma noção mais ampla de acesso à uma ordem jurídica justa, capaz de proporcionar uma tutela jurisdicional eficaz (DONIZETTI, 2017).

\subsection{Direito ao procedimento adequado}

Nas boas palavras de Marinoni, Arenhart e Mitidiero (2016, p. 29) "Diferenciar 
procedimentos implicava diferenciar pessoas e situações [...]”. É por esse motivo que, na época do Estado liberal clássico, quando primava-se pela igualdade formal em prol da liberdade dos particulares, a tutela jurisdicional ignorava as diferentes necessidades e/ou espécies de bens e utilizava-se de um procedimento uniforme a todos.

De igual modo, quando o direito de ação deixou de ser um apêndice do direito material e passou a ser visto como um direito autônomo de natureza pública, surgiu a ideia de que um único procedimento seria capaz de atender diferentes situações de direito substancial. Ledo engano, ao passo que autonomia não é sinônimo de neutralidade e indiferença (MARINONI; ARENHART; MITIDIERO, 2016).

Pensando em ofertar uma tutela jurisdicional adequada por intermédio de procedimentos diferenciados, Didier Jr. (2017) acredita que a natureza do direito litigioso, a evidência pela qual se apresenta o direito material e a urgência da situação processual são os três critérios aos quais o legislador deve observar.

O mesmo autor defende ainda, que além dessa adequação legislativa, o órgão judiciário também deve adequar o processo ao caso concreto, visto que a natural abstração do texto normativo pode ignorar as peculiaridades que só vem à tona numa análise mais detalhada da situação vivenciada (DIDIER JR., 2017).

Assim, os procedimentos especiais são claros exemplos da necessidade de diferenciação do procedimento para atender a uma particular situação de direito substancial, como ocorre com as ações possessórias e de alimentos, por exemplo, onde existem tutelas antecipatórias e meios executivos diferenciados que visam assegurar uma tutela jurídica tempestiva, adequada e efetiva frente a fragilidade do bem em discussão (MARINONI; ARENHART; MITIDIERO, 2016).

Os Juizados Especiais, fortemente marcados pela gratuidade judiciária que possibilita o acesso à justiça dos menos favorecidos, bem como a ação civil pública, a ação popular, dentre outros procedimentos que pretendem proteger os direitos transindividuais, também servem como exemplos quando se fala em procedimentos diferenciados em favor de tutelas adequadas (MARINONI; ARENHART; MITIDIERO, 2016).

O recente Código de Processo Civil em diversos momentos amplia a autonomia do juiz e até mesmo das partes para que possam organizar o procedimento adequadamente as particularidades de cada caso: o art. 139, VI autoriza expressamente que o juiz dilate os prazos e altere a ordem de produção de provas; o art. $373, \S 1^{\circ}$ possibilita a redistribuição do 
ônus da prova; e os próprios negócios jurídicos processuais (art. 190), merecendo esses especial destaque (DIDIER JR., 2017).

Como se vê, o direito processual cada vez mais tem se preocupado em ofertar um procedimento adequado, tempestivo e efetivamente comprometido com o direito material em jogo, “[...] especialmente para casos em que a sua especial configuração tornaria inviável a proteção pela vala comum do procedimento ordinário" (MARINONI; ARENHART; MITIDIERO, 2016, p. 49).

\section{A ESPECIALIZAÇÃO DOS PROCEDIMENTOS LITIGIOSOS DE FAMÍLIA NO CÓDIGO PROCESSUAL DE 2015}

Dentre todas as instituições, tanto públicas como privadas, a família certamente é a mais antiga da história e a que detém maior relevância na formação do indivíduo, visto que é nela que desenvolvem-se hábitos e princípios, bem como formam-se os primeiros laços com outros indivíduos. Consoante muito bem preceituam Monteiro e Silva (2012) ${ }^{1}$ :

Todo homem, ao nascer, torna-se membro integrante de uma entidade natural e social, o organismo familiar. A ela conserva-se ligado durante a sua existência, embora venha a constituir nova família. O entrelaçamento das múltiplas relações, estabelecidas entre os componentes da referida entidade, origina um complexo de disposições, pessoais e patrimoniais, que formam o direito de família

Assim, pensando em ofertar a melhor proteção jurídica a esse complexo e fundamental instituto, o legislador tem trazido inovações no campo do direito familiar, buscando sempre garantir soluções mais eficazes para os embates decorrentes de tais relações. É o que se evidencia da inclusão de todo um capítulo no recente Código de Processo Civil de 2015 para estabelecer um procedimento especial as denominadas ações de família.

\subsection{AÇÕES DE FAMÍLIA E SEU PROCEDIMENTO}

Inovando em relação ao Código de Processo Civil de 1973, que regulava somente a ação de separação judicial consensual como espécie do gênero de procedimentos especiais de jurisdição voluntária, o Código Processual de 2015 dispensou todo o seu Capítulo X, do Título III, do Livro I, da parte Especial, para outorgar um procedimento diferenciado as ações de família de natureza contenciosa (PIMENTEL, 2016).

\footnotetext{
${ }^{1}$ Não contém número de página por tratar-se de documento eletrônico.
} 
A doutrinadora Maria Berenice Dias (2013, p. 87), pouco antes da promulgação do CPC vigente, já manifestava sua indignação com o fato das ações de família não possuírem regulamentação processual específica: "O Código Civil dedica um livro ao direito das famílias. Já o Código de Processo Civil não concede a merecida atenção quando as questões de família batem às portas do Judiciário.”

Assim, o capítulo "Das Ações de Família" do Código de Processo Civil de 2015, estabelecido nos artigos. 693 a 699, institui um procedimento próprio a ser utilizado nas ações litigiosas de divórcio, separação, reconhecimento e extinção de união estável, guarda, visitação e filiação, além de ser aplicado subsidiariamente nas ações de alimentos e nas que versarem sobre os interesses da criança e do adolescente, as quais detém um procedimento estabelecido por legislação específica (NEVES, 2017).

Válido salientar que as demandas familiares, mas de jurisdição voluntária, encontram-se regulamentadas junto ao capítulo dos "Procedimentos Especiais de Jurisdição Voluntária”, em sua Seção de número IV, entre os artigos 731 a 734. Nesse ponto interessante demonstrar a crescente preocupação do legislador com os novos contornos sociais na formação familiar, ao passo que estendeu à união estável a possibilidade de realizar a lavratura de escritura pública de extinção de união estável pelo tabelião, quando assim consentirem os conviventes (DONIZETTI, 2017).

Ao dar prioridade a meios amigáveis de resolução de conflitos, consoante facilmente se pode denotar da leitura do art. $694^{1}$, o Código Processual Civil deixa claro que a decisão judicial baseada em texto de lei ficará adstrita aos casos em que for impossível obter o consenso. Assim, ao alicerçar seu procedimento nos institutos da conciliação e da medição, o rito especial das ações de família buscou conferir as partes a plena satisfação do impasse que lhes aflige, uma vez que a solução é por elas mesmas criada, e não imposta pelo juiz (THEODORO JÚNIOR, 2016).

Outra importante diferença entre o procedimento comum e o de família, reside no fato de que, neste último, a citação ocorrerá com antecedência mínima de quinze dias, enquanto que no primeiro o prazo é ampliado para vinte. No mesmo sentido, o $§ 1^{\circ}$ do art. 695 determina que o mandado de citação contenha exclusivamente os dados necessários para o

\footnotetext{
1 Art. 694. Nas ações de família, todos os esforços serão empreendidos para a solução consensual da controvérsia, devendo o juiz dispor do auxílio de profissionais de outras áreas de conhecimento para a mediação e conciliação.
} 
comparecimento em audiência e esteja desacompanhado da peça inaugural, assegurando-se ao réu o direito de examiná-la a qualquer tempo. O intuito de tais medidas é fazer com que o réu compareça a audiência de conciliação/mediação livre de quaisquer amarras e ideias préestabelecidas que possam dificultar a obtenção de um desfeche amigável (GONÇALVES, 2017).

Mais uma vez, cansativamente reiterando a ideia de se alcançar uma saída pacífica e harmônica às partes, o art. 696 do CPC autoriza que a audiência de conciliação e/ou mediação se divida em tantas sessões quantas julgarem as partes necessárias, observando-se as providências pertinentes para que se evite o perecimento do direito (BUENO, 2017).

Ainda, quanto a audiência em questão, faz-se indispensável que as partes estejam acompanhadas por seus advogados ou defensores públicos no ato, conforme determinação do $\S 4^{\circ}$ do art. 695. Neves (2017) entretanto, entende que não seria caso de nulidade da audiência de conciliação/mediação caso essa ocorra sem a presença de advogado ou defensor público, defendendo a aplicação, nesses casos, do princípio da instrumentalidade das formas, onde a nulidade só seria decretada havendo comprovado prejuízo às partes.

Tendo em vista que os litígios de família não envolvem apenas aspectos jurídicos, mas abarcam significativas cargas emocionais, o art. 699 determinou seja o juiz auxiliado por profissional especialista sempre que necessitar tomar o depoimento da vítima em casos de alienação parental ou abuso. Tal previsão evidencia ainda mais o caráter multidisciplinar da família, uma vez que as ações decorrentes das relações nela existentes, envolvem profissionais de diversificadas áreas (DONIZETTI, 2017).

O Enunciado de número 187 do Fórum Permanente de Processualistas Civis, ao tratar dos artigos $649,165, \S 2^{\circ}$ e 166 , insistiu na ideia de que as partes não poderão ser inibidas quando da tentativa consensual de resolução do conflito familiar: "No emprego de esforços para a solução consensual do litígio familiar, são vedadas iniciativas de constrangimento ou intimidação para que as partes conciliem, assim como as de aconselhamento sobre o objeto da causa" (NEVES, 2017).

Caso após a tomada de todas as providências supra visando uma solução consensual, a mesma ainda restar frustrada, o processo seguirá o procedimento do rito comum, com a intimação do réu em audiência para apresentar contestação em quinze dias. Por conseguinte, ter-se-á a instrução e o julgamento da lide pelo juiz (THEODORO JÚNIOR, 2016). 


\subsubsection{Separação}

No Brasil, até a promulgação da Emenda Constitucional de $n^{\circ}$ 9, em 22 de junho de 1977, a única forma de extinção de um casamento válido se dava com o evento morte. O instituto do "desquite", existente na época, até autorizava os cônjuges a relacionarem-se com terceiros sem cometer adultério, bem como extinguia o regime de bens, mas eles permaneciam oficialmente casados, sendo-lhes vedado contrair novo matrimônio. Veio, então, a Lei de $n^{\circ}$ 6.515/1977 para regular a separação judicial e o divórcio, este último introduzido pela emenda supracitada (DONIZETTI, 2017).

Com a Constituição de 1988, o divórcio ficou condicionado a prévia separação judicial de um ano ou separação de fato por dois anos, nos moldes do $\S 6^{\circ}$ do art. 226. Tal sistema permaneceu vigente até 2010, quando a Emenda Constitucional de $\mathrm{n}^{\mathrm{o}} 66$ dissolveu a obrigação de separar-se para somente então conseguir o divórcio, alterando o mencionado parágrafo para os seguintes termos: "O casamento civil pode ser dissolvido pelo divórcio" (DONIZETTI, 2017).

Apesar de não se mostrar muito compreensível a ideia de alguém querer ter gastos financeiros e emocionais com a realização de uma separação para, posteriormente, ter novos gastos com o divórcio, o Código Civil mantém o instituto da separação nos artigos 1.571 a 1.582, motivo pelo qual o Código Processual de 2015 regulou-o no capítulo das ações de família (ROSA, 2016).

Por seu turno, a Lei $\mathrm{n}^{\mathrm{o}}$ 6.515/77 contém regras de direito material e processual, tendo essas últimas, e somente essas, sofrido interferência do Código Processual de 2015. O art. 34 da Lei do Divórcio, por exemplo, estabelecia que as ações de separação e divórcio litigiosas seguissem o rito ordinário. Tal situação restou expressamente revogada pela instituição de um procedimento especial padrão às ações de família pelo Código em vigor (PIMENTEL, 2016).

Donizetti (2017) atenta-se ao fato de que, caso proposta ação de separação por um dos cônjuges mas o outro pretender o divórcio, poderá esse último formular tal pedido por ocasião de reconvenção, situação em que o primeiro não poderá opor-se ao pleito, visto que de maior abrangência. Ao revés, quando inicialmente proposta ação de divórcio o outro cônjuge intentar ação de separação judicial, faltará a esse interesse processual, devendo ser extinta a ação de separação sem julgamento de mérito por falta de interesse de agir, de acordo com o art. 485, VI do CPC.

Rev. de Processo, Jurisdição e Efetividade da Justiça | e-ISSN: 2525-9814 | Porto Alegre | v. 4 | n. 2 | p. $43-65$ | Jul/Dez. 2018 
Com o trânsito em julgado da ação de separação, será expedido mandado de averbação ao Cartório do Registro Civil de Pessoa Natural. Para os casos de separação extrajudicial, a própria escritura pública se prestará para a averbação. De mesmo modo, o restabelecimento da sociedade conjugal poderá se dar com pedido nos autos ou por escritura pública, ainda que a separação tenha sido judicial, possibilidade prevista pelo art. 48 da Resolução de $n^{\circ}$ 35/2007 do Conselho Nacional de Justiça ${ }^{1}$ (ROSA, 2016).

Com a supressão da separação como requisito para a concessão do divórcio, diversos doutrinadores passaram a entender que tal instituto, especialmente a separação na modalidade judicial, teria deixado de existir. O recente e vigente Código de Processo Civil faz cair por terra tal concepção ao abrigar a separação em seus procedimentos especiais, aclarando que, apesar de tratar-se de mera faculdade, o mesmo ainda vige.

\subsubsection{Divórcio}

Gagliano e Pamploma Filho (2016, p. 522) definem o divórcio como "[...] forma voluntária de extinção da relação conjugal, sem causa específica, decorrente de simples manifestação de vontade de um ou ambos os cônjuges, apta a permitir, por consequência, a constituição de novos vínculos matrimoniais."

Rosenvald e Farias (2015) complementam elucidando que o divórcio poderá se dar judicialmente (consensual ou litigioso) ou administrativamente, essa última por escritura pública, quando não houver interesse de incapaz. Além disso, trata-se de direito personalíssimo (podendo ser provocado exclusivamente por um dos cônjuges) que dissolve a sociedade conjugal, de modo que, ao contrário da separação, se um casal divorciado desejar reatar o casamento, precisará casar-se novamente.

O divórcio altera o estado civil dos cônjuges. Assim, se um dos ex-cônjuges vier a falecer, o estado civil do sobrevivente permanecerá como divorciado(a), de forma diversa ao que acontece na separação onde o cônjuge sobrevivente adquire estado civil como viúvo. No mesmo norte, o indivíduo emancipado pelo casamento nos moldes do art. $5^{\circ}$, parágrafo único, II do Código Civil, não voltará ao statu quo ante diante de um possível divórcio (DIAS, 2013).

\footnotetext{
${ }^{1}$ Art. 48.3 O restabelecirnento de sociedade conjugal pode ser feito por escritura pública, ainda que a separação tenha sido judicial. Neste caso, é necessária e suficiente a apresentação de certidão da sentença de separação ou da averbação da separação no assento de casamento.
} 
Insta salientar, que no divórcio judicial consensual, via de regra, não realizar-se-á a habitual audiência de conciliação/mediação, visto que nesses casos as partes procuram a tutela estatal com acordo previamente entabulado, sem pendências a serem solvidas. Entretanto, em razão de haverem filhos menores de idade, bem como sendo os direitos das crianças e adolescentes indisponíveis, inclusive em relação aos pais, revela-se necessária a vigilância do Ministério Público nessas situações (LÔBO, 2015).

Nesse ponto, ressalva-se, que o Código de Processo Civil de 2015 inovou ao incluir situação que determina a realização do procedimento de divórcio pela via judicial, a saber, a existência de nascituro, consoante art. 733.

Nos procedimentos litigiosos de divórcio, a competência seguirá as determinações estabelecidas pelo art. 53, I do Código de Processo Civil: primeiramente no domicílio do guardião do filho incapaz; não havendo filhos incapazes, no último domicílio do casal; por fim, se nenhuma das partes residir em seu antigo domicílio, será ajuizada no domicílio do réu. Com tal determinação o legislador procurou aproximar-se da discutida e almejada igualdade de gêneros vivenciada atualmente, uma vez que o art. 100, I do antigo Código Processual estabelecia prerrogativa de foro à mulher nas ações de família (ROSA, 2016).

Acerca do convívio em matrimônio até o fim da demanda de divórcio litigioso, nas palavras de Donizetti (2017, p. 868), “A convivência em família, sobretudo quando a base afetiva já ruiu, pode dar azo a discórdias e agressões". Foi por isso o legislador ofertou meios de garantir a integridade física e moral da parte que venha a requerer o fim da sociedade conjugal, como a concessão de tutelas cautelares de caráter antecedente (art. 305 CPC) que se prestarão ao mesmo fim.

Ressalta-se que a ação de divórcio poderá abrigar matérias subjacentes à extinção do casamento, como a guarda dos filhos, o regime de visitação, a partilha dos bens, prestação de alimentos, dentre outros. Pensando nessas situações, e por tratar-se o divórcio de um direito potestativo que independe de maior produção probatória, bastando a vontade de um dos cônjuges em dissolver a sociedade conjugal, foi que o Instituto Brasileiro de Direito de Família (IBDFAM) estipulou em seu enunciado de $\mathrm{n}^{\mathrm{o}} 18^{1}$ o julgamento parcial do mérito nesses casos, devendo prosseguir a demanda acerca dos demais atritos (ROSA, 2016).

\footnotetext{
${ }^{1}$ Enunciado 18. Nas ações de divórcio e de dissolução da união estável, a regra deve ser o julgamento parcial do mérito (art. 356 do Novo CPC), para que seja decretado o fim da conjugalidade, seguindo a demanda com a discussão de outros temas.
} 
A sentença que reconhece o divórcio detém natureza desconstitutiva e deverá ser averbada no registro civil, bem como no registro imobiliário caso haja bens (DIAS, 2013).

Buscando a celeridade e a resolução consensual de conflitos típicas do recente Código de Processo Civil, já a Resolução de $n^{\circ} 35 / 2007^{1}$ do CNJ previa a possibilidade de desistência do divórcio na esfera judicial para a promoção da via extrajudicial, ou até mesmo sua suspensão pelo prazo de trinta dias (ROSA, 2016).

\subsubsection{Reconhecimento e extinção de união estável}

Apesar de fortemente condenada pela Igreja e, consequentemente, pela sociedade como um todo durante boa parte da história, a união afetiva sem as formalidades matrimoniais sempre existiu. O Código Civil de 1916, que foi revogado há menos de duas décadas, qualificava a entidade familiar decorrente do casamento como "família legítima" e as demais como "ilegítimas", por exemplo. Desse modo, a família detinha uma compreensão exclusivamente matrimonial, deixando-se de lado da proteção do direito de família aquelas constituídas fora do casamento (ROSENVALD; FARIAS, 2015).

Entretanto, considerando-se que a separação e o divórcio também são institutos relativamente recentes, e que até a sua criação o casamento só poderia ser dissolvido pelo evento morte, eram comuns os casos em que indivíduos conviviam maritalmente, mas que optavam ou não podiam contrair casamento. Nesse contexto, surgiu uma enxurrada de ações pleiteando direitos decorrentes do rompimento de vínculos conjugais não oriundos do matrimônio. Até que em 1964, o Supremo Tribunal Federal pacificou o entendimento que reconhecia os relacionamentos não matrimonias como sociedades de fato, gerando assim direitos obrigacionais entre os companheiros, por meio da Súmula 380: "Comprovada a existência de sociedade de fato entre os concubinos, é cabível a sua dissolução judicial, com a partilha do patrimônio adquirido pelo esforço comum.” (DONIZETTI 2017).

Com o passar do tempo e a aceitação da sociedade, a Constituição de 1988 reconheceu expressamente a união estável no parágrafo $3^{\circ}$ de seu art. 226, nos seguintes termos: "Para efeito da proteção do Estado, é reconhecida a união estável entre o homem e a mulher como entidade familiar, devendo a lei facilitar sua conversão em casamento." (DIAS,

\footnotetext{
${ }^{1}$ Art. $2^{\circ}$ É facultada aos interessados a opção pela via judicial ou extrajudicial; podendo ser solicitada, a qualquer momento, a suspensão, pelo prazo de 30 dias, ou a desistência da via judicial, para promoção da via extrajudicial.
}

Rev. de Processo, Jurisdição e Efetividade da Justiça | e-ISSN: 2525-9814 | Porto Alegre | v. 4 | n. 2 | p. $43-65$ | Jul/Dez. 2018 
2013).

Gagliano e Pamplona Filho (2016, p. 417) de forma sintética revelam a evolução terminológica que a união afetiva sem matrimônio sofreu ao longo da história: "concubinato, união livre, união de fato, união consensual, união estável...”.

Ademais das características históricas que definem esse instituto, Lôbo $(2015)^{1}$ muito bem o conceitua:

\begin{abstract}
A união estável é a entidade familiar constituída por duas pessoas que convivem em posse do estado de casado, ou com aparência de casamento (more uxório). É um estado de fato que se converteu em relação jurídica em virtude de a Constituição e a lei atribuírem-lhe dignidade de entidade familiar própria, com seus elencos de direito e deveres. Ainda que o casamento seja sua referência estrutural, é distinta dele; cada entidade é dotada de estatuto jurídico próprio, sem hierarquia ou primazia.
\end{abstract}

Além disso, a informalidade é uma característica marcante da união estável, ao passo que ela não precisa passar por um procedimento específico e rígido como o casamento, mas ela simplesmente acontece. Como requisitos da união estável pode-se mencionar a convivência duradoura, pública e contínua, com o intuito de constituir família; salientando-se que o Superior Tribunal Federal já sumulou ${ }^{2}$ o entendimento de que não há necessidade de coabitação para o reconhecimento da união estável. (ROSA, 2016).

O Código de Processo Civil de 2015 inovou ao regular as ações de união estável, tanto aquelas de jurisdição contenciosa (art. 693), como as consensuais (art. 732). Os pressupostos para o reconhecimento da união estável são obtidos por exclusão, consoante art. $1.723, \S 2^{\circ}$ : “A união estável não se constituirá se ocorrerem os impedimentos do art. 1.521". Por seu turno, o art. 1.521 proíbe a união entre ascendentes e descendentes; afins em linha reta; adotante com quem foi cônjuge do adotado e o adotado com quem o foi do adotante, irmãos, unilaterais ou bilaterais, e demais colaterais, até o terceiro grau inclusive; adotado com o filho do adotante; as pessoas casadas, desde que não estejam separadas de fato; cônjuge sobrevivente com o condenado por homicídio ou tentativa de homicídio contra o seu consorte (PIMENTEL, 2016).

No mais, o procedimento de reconhecimento ou extinção de união estável litigioso seguirá as mesmas premissas estabelecidas à separação e ao divórcio, iniciando-se com a

\footnotetext{
${ }^{1}$ Não contém número de página por tratar-se de documento eletrônico.

${ }^{2}$ Súmula 382 - A vida em comum sob o mesmo teto, more uxorio, não é indispensável à caracterização do concubinato.
}

Rev. de Processo, Jurisdição e Efetividade da Justiça | e-ISSN: 2525-9814 | Porto Alegre | v. 4 | n. 2 | p. $43-65$ | Jul/Dez. 2018 
audiência de conciliação/mediação e, não havendo composição, a parte ré será intimada a apresentar contestação (DONIZETTI, 2017).

Rosenvald e Farias (2015) entendem pelo cabimento da ação de reconhecimento de união estável inclusive enquanto as partes estiverem convivendo de fato, independentemente de provável dissolução ou não. Isso porque há claro interesse de agir quanto a possibilidade de direitos futuros decorrentes da união afetiva, reconhecidos aos companheiros.

Também é possível a interposição da ação de reconhecimento ou extinção de união estável após o falecimento de um dos conviventes, caso em que deverá ser ajuizada em face dos sucessores, citando-se todos os herdeiros necessários. De mesmo modo, poderá ser proposta pelos herdeiros do companheiro falecido em face do sobrevivente (ROSA, 2016).

Insta frisar, por fim, que o art. 1.725 do Código Civil determina a aplicação do regime da comunhão parcial de bens à união estável, a menos que haja pactuação escrita em sentido diverso.

\subsubsection{Guarda, visitação e filiação}

Os pleitos relativos à guarda, direito de visitas e filiação poderão se dar tanto em ação autônoma, como incidentalmente em outras ações relativas a direitos de família (separação, divórcio, reconhecimento e extinção de união estável). Se primeiramente, tais pedidos foram requeridos de forma incidental, nada impede que, posteriormente, com a mudança do contexto fático vivenciado, seja proposta nova ação autônoma, especificamente sobre a mudança desejada. Além disso seguirão o procedimento das ações de família estabelecido nos artigos 693 a 699 do Código de Processo Civil supra já elucidado (DONIZETTI, 2017).

Importa frisar, que o Código Processual Civil de 2015 em nada revogou as prerrogativas do Estatuto da Criança e do Adolescente (Lei n ${ }^{\circ}$ 8.069/1990) ou da Lei de Alimentos (Lei n ${ }^{\circ}$ 5.478/1968). Pelo contrário, o parágrafo único do art. 693 deixa claro que tais procedimentos seguirão lei específica, aplicando-se o Código Processual apenas subsidiariamente (PIMENTEL, 2016).

Acerca dos institutos abrigados no presente tópico, cumpre tornar claro o conceito de "poder familiar", denominado "pátrio poder" pelo Código Civil de 1916. Assim, para Gagliano e Pamplona Filho (2016, p. 598) o poder familiar pode ser entendido "como o plexo 
de direitos e obrigações reconhecidos aos pais, em razão e nos limites da autoridade parental que exercem em face dos filhos, enquanto menores e incapazes."

Nesse norte, a guarda é um dos deveres do poder familiar reconhecido expressamente no inciso II, do art. 1.634 do Código Civil, prestando-se aos interesses e à proteção da criança e do adolescente ao responsabilizar o seu detentor em garantir ao menor incapaz assistência material, moral e educacional. A detenção da guarda por apenas um dos genitores (guarda unilateral) não destitui o outro do poder familiar (art. 1.632 do CC), mas confere ao guardião o poder decisório na criação e educação no melhor interesse do menor de idade, cabendo ao outro genitor fiscalizar e reclamar judicialmente quando o exercício da guarda estiver sendo exercida de maneira prejudicial à criança e ao adolescente (CARVALHO, 2015).

Entretanto, a guarda também poderá se dar de forma compartilhada onde o poder familiar será exercido de forma conjunta e harmônica por ambos os genitores. $\mathrm{O}$ art. 1.583, também do Código Civil, em seu $\S 1^{\circ}$ diferencia a guarda unilateral da compartilhada:

Art. 1.583. A guarda será unilateral ou compartilhada.

$\S 1^{\circ}$ Compreende-se por guarda unilateral a atribuída a um só dos genitores ou a alguém que o substitua (art. 1.584, $\S 5^{\circ}$ ) e, por guarda compartilhada a responsabilização conjunta e o exercício de direitos e deveres do pai e da mãe que não vivam sob o mesmo teto, concernentes ao poder familiar dos filhos comuns.

A Lei de $n^{\circ} 13.058 / 2014$, que alterou a redação do art. $1.584, \S 2^{\circ}$, estabeleceu que, como regra, a guarda será compartilhada, salvo se um dos genitores declarar ao magistrado que não deseja deter a guarda do menor de idade. Destarte, na audiência de conciliação/mediação das ações que contiverem pedidos de guarda, caberá ao juiz elucidar acerca do sentido da guarda compartilhada, alertando sobre sua importância, direitos, deveres e sansões decorrentes do seu descumprimento (art. 1.584, $\S 1^{\circ}$ ) (DONIZETTI, 2017).

No mesmo norte, o direito de visitas, também compreendido como direito a companhia ou convivência, é nada além de uma contrapartida da guarda exclusiva. Seu exercício depende de prévia convenção entre os genitores ou do que melhor decidir o magistrado em prol do menor. Aqui, o juiz deverá tomar as devidas cautelas para que os interesses dos pais não se sobreponham ao direito de convívio do filho, visto que, não são raras as situações em que sentimentos de mágoa e remorso decorrentes da separação se embaralham na cabeça do genitor, que passa a dificultar a convivência do filho com o não guardião e vice-versa (LÔBO, 2015).

O direito à convivência familiar é reconhecido constitucionalmente (art. 227, caput) e 
cada vez mais a jurisprudência tem disseminado a ideia de que deve ser exercido de forma proporcional entre os genitores, evitando-se a formação de pais que se façam presentes exclusivamente de maneira recreativa em finais de semana alternados. O enunciado 606 das Jornadas de Direito Civil revela-se em igual sentido:

\footnotetext{
O tempo de convívio com os filhos "de forma equilibrada com a mãe e com o pai" deve ser entendido como divisão proporcional de tempo, da forma que cada genitor possa se ocupar dos cuidados pertinentes ao filho, em razão das peculiaridades da vida privada de cada um.
}

Buscando evitar o descumprimento do direito garantido ao menor, o genitor que tiver a convivência com seu filho deturpada poderá registrar o ocorrido por intermédio de ata notarial, requisitando que o tabelião se faça presente junto à retirada ou entrega da criança no local combinado. A ata notarial servirá também para comprovar a veracidade de troca de mensagens em redes sociais entre os genitores. Os Tribunais têm, inclusive, procurado efetivar o direito em tela por meio de astreintes proporcionais ao poder econômico daquele que descumpre sua função (ROSA, 2016).

Quanto à filiação, reconhecida por Rosenvald e Farias (2015) como a mais relevante entre as múltiplas relações de parentesco, a Carta Magna de 1988 foi transparente ao condenar todo e qualquer tipo de discriminação em seu art. $227, \S 6^{\circ}$ : "Os filhos, havidos ou não da relação do casamento, ou por adoção, terão os mesmos direitos e qualificações, proibidas quaisquer designações discriminatórias relativas à filiação.”

A filiação será provada por meio de certidão do termo de nascimento, no cartório de registro civil de pessoas naturais do local do parto ou da residência dos pais (art. 1.603 CC) e será feita pelo pai e pela mãe, isoladamente ou em conjunto, ou, na falta desses, por parente próximo, administrador do hospital, médico ou parteira, pessoa idônea que tenha presenciado o parto, ou pessoa encarregada da guarda do menor (art. 52 da Lei 6.015/1973) (CARVALHO, 2015).

O reconhecimento da filiação ocorrerá de forma voluntária pelos pais, conjunta ou separadamente (art. 1.607 CC), judicialmente através de ação de investigação de paternidade, ou por intermédio de averiguação oficiosa. A averiguação oficiosa é um procedimento administrativo, sem caráter judicial, mas que contém a presença da figura do magistrado e se inicia pelo oficial do cartório de registro civil de pessoas naturais quando o registro constar apenas a maternidade. Tal instituto busca regularizar de forma mais econômica e célere o 
plano familiar da criança e foi instituído pela Lei no 8.560/1992 (ROSA, 2016).

\section{EFICÁCIA OU UTOPIA DO DIREITO AO PROCEDIMENTO ADEQUADO NOS PROCEDIMENTOS LITIGIOSOS DE FAMÍLIA}

Os procedimentos especiais contenciosos, na estrutura do Código de Processo Civil vigente, são aqueles que se destinam a situações específicas e que se demonstram total ou parcialmente distintos do procedimento comum. Por intermédio dos procedimentos especiais é possível identificar a simetria que deve existir entre o direto processual para com o direito material, sempre com o fim maior de alcançar-se uma eficiente prestação jurisdicional por meio de um procedimento adequado (THEODORO JÚNIOR, 2016).

Por seu turno, Gagliano e Pamplona Filho (2016) acreditam que dentre os ramos de direito civil, o direito de família é aquele com maior dinamicidade, seja no campo das novas relações diariamente estabelecidas em sociedade, quanto na elaboração de novos textos legais.

O caráter dinâmico e multidisciplinar que o instituto da família traz consigo fica claro nas palavras de Rosenvald e Farias (2015, p. 4):

Induvidosamente, a família traz consigo uma dimensão biológica, espiritual e social,
afigurando-se necessário, por conseguinte, sua compreensão a partir de uma feição
ampla, considerando suas idiossincrasias e peculiaridades, o que exige a participação
de diferentes ramos do conhecimento, tais como a sociologia, a psicologia, a
antropologia, a filosofia, a teologia, a biologia (e, por igual, da biotecnologia e a
bioética) e ainda, da ciência do direito.

Foi pensando nas particularidades e na complexidade das questões familiares, que abrigam face tipicamente emocional em seu bojo, que o recente Código Processual Civil diferenciou-se dos anteriores ao ofertar um procedimento específico e adequado às ações litigiosas de família. A dúvida reside em saber se essa novidade demonstrou-se suficiente para conferir eficácia a essa modalidade de demanda judicial.

Ademais da certeza de que somente a prática forense será capaz de solucionar a incerteza supra, alerta-se para o fato de que é impossível ao legislador estabelecer tantos procedimentos diferenciados quantos sejam os possíveis casos concretos que batam às portas do Judiciário em busca de uma solução eficaz (MARINONI; ARENHART; MITIDIERO, 2016).

Apesar das ações contenciosas de família possuírem um procedimento especializado que as norteie, são inúmeras as causas que poderão ensejar uma demanda judicial, dentre elas,

Rev. de Processo, Jurisdição e Efetividade da Justiça | e-ISSN: 2525-9814 | Porto Alegre | v. 4 | n. 2 | p. $43-65$ | Jul/Dez. 2018 
como visto, a separação, o divórcio, o reconhecimento e a extinção de união estável, a regulamentação do direito de visitas, guarda, dentre outras. Além disso, nenhuma ação de divórcio é idêntica a outra, visto que numa podem haver filhos, noutra não, numa os filhos podem ser maiores e capazes, noutra não, numa eles desejam permanecer exclusivamente sob a guarda da mãe, noutra sob guarda compartilha... Enfim, o jargão "cada caso é um caso" mostra-se veraz!

Entretanto, Marinoni, Arenhart e Mitidiero (2016) atentam-se também ao fato de que várias das reformas realizadas ainda no Código de Buzaid, como o instituto da antecipação dos efeitos da tutela (art. 273) nos casos de fundado receio de dano, abuso do direito de defesa e parte incontroversa da demanda, já introduziam normas abertas capazes de satisfazer as necessidades da demanda conforme o caso concreto em análise. A partir daí, o procedimento passou a adequar-se as circunstâncias da situação em análise, ao invés de, exclusivamente, buscar-se um procedimento que satisfizesse as necessidades de tutela do direito material pleiteado.

O recente e vigente Código de Processo Civil manteve a ideia de normas processuais abertas, levemente pinceladas pelo Código revogado, fomentando a flexibilização procedimental. É o que se pode vislumbrar em artigos como o 139, VI, que autoriza o juiz a "dilatar os prazos processuais e alterar a ordem de produção dos meios de prova, adequandoos às necessidades do conflito de modo a conferir maior efetividade à tutela do direito", bem como nos artigos 190 e 191 que autorizam o que se denomina de negócio jurídico processual, conferindo às partes autonomia para fixar calendário diferenciado a prática dos atos processuais e realizar mudanças no procedimento a fim de melhor ajustá-lo as especificidades e necessidades de cada caso concreto. Conforme Marinoni, Arenhart e Mitidiero sobre a previsão de tais normas (2016, p. 58):

\footnotetext{
Regras como essas, obviamente, permitem quase que a "construção" de um procedimento adequado ao caso concreto, com a interveniência do órgão judiciário e das partes. Assim, rompe-se com a estrutura rígida dos procedimentos especiais antigos e da pretensão ao procedimento único liberal, para entregar aos protagonistas do processo a possibilidade de adequar o procedimento ao caso concreto.
}

Assim sendo, ainda que as particularidades de cada caso concreto demandem adequações procedimentais por meio de normas abertas como as supra mencionadas que, sem a menor dúvida vem ao encontro da efetivação do direito ao procedimento adequado, a 
sobrecarga do Judiciário que não raro mecaniza o trabalho dos operadores do direito, inviabiliza tal adequação. Por tal motivo, a criação pelo legislador de procedimentos especiais consoante o direito material em litígio, como o fez o novo Código de Processo Civil com as ações de família, é medida louvável e que gera grandes avanços no que tange a adequação procedimental.

\section{CONCLUSÃO}

O presente artigo buscou investigar como a especialização dos procedimentos litigiosos de família pelo jovem Código de Processo Civil de 2015 poderia assegurar o direito das partes a um procedimento adequado e, consequentemente, um efetivo acesso à justiça.

Inicialmente, verificou-se que o direito fundamental de acesso à justiça vai muito além da simples possibilidade de poder postular em juízo, mas sim, relaciona-se com a ideia de um acesso a uma ordem jurídica justa, seja judicial ou extrajudicialmente. Entretanto, são diversos os obstáculos a serem enfrentados para que se possa garantir um efetivo acesso à justiça. Apesar de movimentos históricos, denominados "ondas renovatórias", terem buscado enfrentar tais empecilhos, o direito constitucional de acesso à justiça é dinâmico e acompanha as necessidades vivenciadas pela evolução.

Nesse sentido, entendeu-se que o direito ao procedimento adequado pode ser vislumbrado como um braço do direito fundamental de acesso à justiça, visto que em sua máxima, procura garantir um processo mais célere, eficiente e capaz de conferir a "justiça" almejada pelas partes. Válido tornar claro que, enquanto que o processo se revela como o mecanismo utilizado pelo Estado para dirimir litígios quando provocado, o procedimento é o conjunto de atos e fórmulas que conferem uma ordem legal ao processo.

Nesse contexto, o recente Código de Processo Civil de 2015 demonstrou clara preocupação com a necessidade de ofertar procedimentos capazes de garantir a efetiva realização do direito material em disputa. A especialização das demandas contenciosas de família e a gritante preocupação do legislador em fomentar soluções consensuais, consequentemente conferindo celeridade e eficácia processual, são bons exemplos dessa mencionada preocupação.

A previsão de uma audiência preliminar de conciliação ou mediação como regra no procedimento comum (art. 334), o reconhecimento do instituto da arbitragem e da expressa determinação para estimular a conciliação e a mediação durante todo o curso do processo já 
no seu art. $3^{\circ}$, sendo tal ideia reiterada no capítulo dedicado às ações de família, deixam clara a intenção do Código Processual de 2015 em incentivar meios alternativos que se revelem mais adequados a cada caso em análise.

Identificou-se ainda, que o instituto da família, além de se revelar como o mais antigo da história e de maior relevância para o particular, também é extremamente complexo e dinâmico, envolvendo fatores emocionais, culturais e biológicos em sua formação. Assim, não foi por menos que restou estabelecido pelo Código Processual de 2015, que nas ações litigiosas de família o juiz dispõe do auxílio de profissionais de outras áreas de conhecimento (psicológica, assistência social) para a realização de mediação/conciliação.

Contudo, ainda que a criação inusitada de um procedimento específico aos litígios que abarquem direitos de família seja louvável, é impossível ao legislador conferir tantos procedimentos quantos sejam as possíveis situações familiares a buscar a tutela jurisdicional. Isso porque, na prática, nenhum caso concreto será estritamente igual a outro.

Assim sendo, o legislador apostou, no Código de Processo Civil de 2015, em normas abertas capazes de serem adequadas as particularidades do caso trazido à baia. A exemplo, tem-se o art. 139, VI que possibilitou ao magistrado dilatar prazos e alterar a ordem de produção de provas conforme as necessidades da demanda de modo a conferir maior efetividade à tutela do direito. No mesmo sentido, os artigos 190 e 191, garantem as partes a autonomia para fixarem um calendário processual diferenciado e realizar mudanças no procedimento a fim de melhor ajustá-lo as suas necessidades, situação denominada de negócio jurídico processual.

Ocorre que, ainda que tais normas abertas venham ao encontro da efetivação do direito ao procedimento adequado, é certo que o excesso de processos e a falta de funcionários nem sempre permitem que Poder Judiciário se debruce sobre cada caso em particular e busque aplicá-las. Sabendo-se disso é que se acredita que a aproximação do direito processual às carências do direito material objeto da lide, como fez o legislador ao conferir um procedimento especial às ações litigiosas de família pelo jovem Código de Processo Civil de 2015, garante o que mais próximo se pode chegar, no contexto atual, do direito ao procedimento adequado.

\section{REFERÊNCIAS}

Rev. de Processo, Jurisdição e Efetividade da Justiça | e-ISSN: 2525-9814 | Porto Alegre | v. 4 | n. 2 | p. $43-65$ | Jul/Dez. 2018 
BEZERRA, Paulo César. Acesso à justiça: um problema ético-social no plano da realização do direito. Rio de Janeiro: Renovar, 2001. 284p.

BRASIL. Constituição: República Federativa do Brasil de 1988. Brasília, DF: Senado Federal, 1988, Disponível em:

<http://www.planalto.gov.br/ccivil_03/constituicao/constituicaocompilado.htm>. Acesso em: 30 ago. 2017.

BRASIL. Código de Processo Civil. Lei n. 13.105, de 16 de março de 2015. Diário Oficial da União, Brasília, DF, 16 mar. 2015. Disponível em: <http://www.planalto.gov.br/ccivil_03/_ato2015-2018/2015/lei/113105.htm> Acesso em 16 ago. 2017.

BUENO, Cassio Scarpinella. Manual de direito processual civil: volume único. 3. ed. São Paulo: Saraiva, 2017. 824 p.

CÂMARA, Alexandre Freitas. Lições de Direito Processual Civil. Rio de Janeiro: Lumen Júris, 2004. p. 540.

CAPPELLETTI, Mauro; GARTH, Bryant. Acesso à justiça. Porto Alegre: SAFE, 1988. 168 p.

CAOVILLA, Maria Aparecida Lucca. Acesso à justiça e cidadania. 2. ed., rev. e ampl. Chapecó, SC: Argos, 2006. 227 p.

CARVAlHO, Dimas Messias de. Direito das famílias. 4. ed. São Paulo: Saraiva, 2015. Disponível em: <https://app.saraivadigital.com.br/leitor/epub:164090> Acesso em 02 set. 2017.

DIAS, Maria Berenice. Manual de direito das famílias. 9. ed. São Paulo: Revista dos Tribunais, 2013. $717 \mathrm{p}$.

DIDIER JUNIOR, Fredie. Curso de direito processual civil: introdução do direito processual civil, parte geral e processo de conhecimento. 19. ed. Salvador: JusPodivm, 2017. 879 p.

DONIZETTI, Elpídio. Curso didático de direito processual civil. 20. ed. Rio de Janeiro: Atlas, 2017. $1460 \mathrm{p}$.

FARIAS, Cristiano Chaves de; ROSENVALD, Nelson. Curso de direito civil: famílias. 7. ed. Rio de Janeiro: São Paulo: Atlas, 2015. 970 p.

GAGLIANO, Pablo Stolze; PAMPLOMA FILHO, Rodolfo. Novo curso de direito civil: direito de família: as famílias em perspectiva constitucional. 6. ed. São Paulo: Saraiva, 2016. $784 \mathrm{p}$. 
GONÇALVES, Marcus Vinicius Rios. Novo curso de direito processual civil: processo de conhecimento ( $2^{\mathrm{a}}$ parte) e procedimentos especiais. 13. ed. São Paulo: Saraiva, 2017. 408 p.

LÔBO, Paulo. Direito civil: famílias. 6. ed. São Paulo: Saraiva, 2015. Disponível em: <https://app.saraivadigital.com.br/leitor/epub:165241>. Acesso em: 15 ago. 2017.

MARINONI, Luiz Guilherme; MITIDIERO, Daniel; ARENHART, Sérgio Cruz. Novo código de processo civil comentado: teoria do processo civil. 2. ed. São Paulo: Revista dos Tribunais, 2016. 636 p.

MARINONI, Luiz Guilherme; MITIDIERO, Daniel; ARENHART, Sérgio Cruz. Novo código de processo civil comentado: tutela dos direitos mediante procedimentos diferenciados. 2. ed. São Paulo: Revista dos Tribunais, 2016. 541 p.

MONTEIRO, Washington de Barros; SILVA, Regina Beatriz Tavares da. Curso de direito civil, 2. 42. ed. São Paulo: Saraiva, 2012. Disponível em:

<https://app.saraivadigital.com.br/leitor/epub:2086>. Acesso em: 14 ago. 2017.

NEVES, Daniel Amorim Assumpção. Manual de direito processual civil: volume único. 9. ed. Salvador, BA: JusPodivm, 2017. 1807 p.

PIMENTEL, Alexandre Freire. O procedimento das ações de família (de jurisdição contenciosa e voluntária) no CPC/2015. Revista da AJURIS, Porto Alegre, v. 43, n. 141, dez. 2016. Disponível em:

$<$ https://www.google.com.br/url?sa=t\&rct=j\&q=\&esrc=s\&source=web\&cd=6\&ved=0ahUKE wji6MWJ99fVAhXFkJAKHX-

ED8gQFghEMAU\&url=http\%3A\%2F\%2Fwww.ajuris.org.br\%2FOJS2\%2Findex.php\%2FRE VAJURIS\%2Farticle\%2Fdownload\%2F627\%2FAjuris141_DT3\&usg=AFQjCNGfZ3k2yBdx 29_aRjlkh4UqHicvmA>. Acesso em 15 ago. 2017.

RODRIGUES, Horácio Wanderlei; LAMY, Eduardo de Avelar. Teoria geral do processo. 4. ed. Rio de Janeiro: Elsevier, 2016. 452 p.

ROSA, Conrado Paulino da. Curso de direito de família contemporâneo. Salvador: JusPodivm, 2016. 496 p.

THEODORO JÚNIOR, Humberto. Curso de direito processual civil: teoria geral do direito processual civil, processo de conhecimento, procedimento comum. 58. ed., rev., atual e ampl. Rio de Janeiro: Forense, 2017. 1256 p.

THEODORO JÚNIOR, Humberto. Curso de direito processual civil: procedimentos especiais. 50. ed., rev., atual e ampl. Rio de Janeiro: Forense, 2016. xxxii, 869 p. 